Supplementary Information of

\title{
Impact of locational choices and consumer behaviors on personal land footprints: An exploration across the urban-rural continuum in USA
}

Lin Zeng ${ }^{1,2 *}$, Anu Ramaswami ${ }^{1,2}$

1. Center for Science, Technology, and Environmental Policy, Hubert H. Humphrey School of

Public Affairs, University of Minnesota, Minneapolis, Minnesota 55455, United States

2. Department of Civil and Environmental Engineering, Princeton University, Princeton, New Jersey 08544, United States

Number of pages: 18

Number of figures:1

Number of tables:7 


\section{Land use data compilation for EEIO}

2 Various U.S. Federal agencies produce land use or land cover estimates. The scope and scale of

3 the estimates differ widely. For example, Census of agriculture accounted the agricultural land use

4 based on the land area in farms ${ }^{1}$, but $11.6 \%$ out of it was categorized as forest land and other land

5 use in USDA's Major Land Use (MLU) report ${ }^{2}$. For summary and comparison of the land use and

6 land cover estimates produced by different US agencies, please refer to USDA's website ${ }^{3}$.

7 We choose USDA ERS' Major Land Use (MLU) report as our primary data source since it is

8 the most comprehensive accounting of all major uses of public and private land in the United

9 States. Details of how each type of land use is use to derive the satellite table is described as

10 follows. We generally followed the land allocation method proposed by USEEIO ${ }^{4}$, and improved

11 it to make sure all land use can add up to total U.S. land area (2260 million acres) when needed

12 (i.e., Get rid of double counting, etc.)

13 The total amount of cropland land and grazing land (excluding grazed forest land), 379 and 668

14 million acres, respectively, is directly from the MLU report. This total amount was allocated to

15 relevant agricultural sectors based on 2012 USDA Census of Agriculture which provides shares

16 of nation-wide land in farms for crop and animal production by 4 or 5 -digit NAICS code ${ }^{5}$. Grazed

17 forestland, 130 million acres in total, was allocated to sectors based on shares of farm land as

18 follows: $92 \%$ to beef cattle ranching and farming, $5 \%$ to dairy cattle and milk production, and 3\%

19 to animal production, except cattle and poultry and eggs 5 .

20 Land use for mining, oil, and gas extraction activities was estimated based on the Bureau of

21 Land Management (BLM) Public Land Statistics 2012 report $^{6}$. In all cases except hard rock leases,

22 the BLM data could be mapped to a sector in the EEIO model without allocation. Hard rock leases 
23 were allocated to relevant mining sectors based on shares of employee compensation from the

24 BEA's 2012 Use tables?

25 The land area associated with commercial and manufacturing buildings was estimated based on

26 the building floorspace data provided by the U.S. Energy Information Administration (EIA) 2012

27 Commercial Building Energy Consumption Survey (CBECS) ${ }^{8}$ and 2010 Manufacturing Energy

28 Consumption Survey (MECS) ${ }^{9}$. In addition, the additional land area associated with commercial

29 and manufacturing facilities, e.g. parking, signage, and landscaped area, was estimated by

30 assuming a ratio of 3 to total floorspace, which followed the USEEIO's assumption. For more

31 details, please refer to the USEEIO's documentation ${ }^{4}$. Estimates for other land use including

32 timberland land and national defense areas were also based on the MLU report.

33 Total land in urban use in the United States was estimated at 70 million acres in 2012. The urban

34 and rural residential land area in the United States are estimated as 106.3 and 32.8 million acres

35 respectively derived from American housing survey data ${ }^{10}$. Urban transportation land use is

36 estimated by subtracting urban residential land, commercial and manufacturing land use, and open

37 space (assuming $10 \%$ of urban area ${ }^{11}$ ) by the total land in urban use in the United States ( 70 million

38 acres in 2012). Land use in urban area for airports and railroads were each assumed 5\% of the total

39 use of urban land. Parking in urban area was estimated as $25 \%$ of the local road area ${ }^{12,13}$. Total

40 land use for both urban and rural highways/roads was allocated to relevant transportation sectors

41 based on the shares of Federal Highway Administration fees: $32.9 \%$ to truck transportation, $0.1 \%$

42 to transit and ground passenger transportation, $0.1 \%$ to state and local government passenger

43 transit, and $66.9 \%$ to personal consumption expenditures ${ }^{14}$. National parks are not included in our

44 analysis. They are noted as other lands consistent with USEEIO methodology. Table S1 below

45 shows the total land use allocation and detailed data source used in the paper. 
Table S1 Total land use and data source used in the paper (Unit: Million acres)

\begin{tabular}{|c|c|c|c|c|}
\hline & & Land use type & Amount & Data source \\
\hline \multirow{9}{*}{$\begin{array}{l}\text { Allocate } \\
\text { production } \\
\text { sectors }\end{array}$} & \multirow[t]{9}{*}{ to } & Timberland & 502 & Major Uses of Land in 2012 report $^{2}$ \\
\hline & & Cropland & 379 & $\begin{array}{l}\text { Major Uses of Land in } 2012 \\
\text { report }^{2} \text {, Census of Agriculture } \\
2012^{1}\end{array}$ \\
\hline & & Grazing land & 798 & Major Uses of Land in 2012 report $^{2}$ \\
\hline & & Mining & 41 & BLM 2012, public land statistics ${ }^{6}$ \\
\hline & & $\begin{array}{l}\text { Transportation (highways/roads for } \\
\text { freight and buses, railways, airports, } \\
\text { parking) }\end{array}$ & 23 & $\begin{array}{l}\text { Major Uses of Land in } 2012 \\
\text { report }^{2} \text {, Federal Highway Statistics } \\
2012^{12}\end{array}$ \\
\hline & & Commercial land & 7 & $\begin{array}{l}\text { EIA 2015, Commercial Buildings } \\
\text { Energy Consumption Survey } \\
(\mathrm{CBECS})^{8}\end{array}$ \\
\hline & & Manufacturing land & 1 & $\begin{array}{l}\text { EIA 2013, Manufacturing Energy } \\
\text { Consumption Survey (MECS) }\end{array}$ \\
\hline & & National defense area & 27 & Major Uses of Land in 2012 report $^{2}$ \\
\hline & & Sum of production sectors: & 1778 & \\
\hline \multirow[t]{5}{*}{$\begin{array}{l}\text { Allocate } \\
\text { households }\end{array}$} & \multirow[t]{5}{*}{ to } & Urban residential lot area & 33 & $\begin{array}{l}\text { American housing survey }{ }^{10} \text {, Major } \\
\text { Uses of Land in } 2012 \text { report }^{2}\end{array}$ \\
\hline & & Rural residential lot area & 106 & $\begin{array}{l}\text { American housing survey }{ }^{10} \text {, Major } \\
\text { Uses of Land in } 2012 \text { report }^{2}\end{array}$ \\
\hline & & Urban Green space and public parks & 7 & Larson 2016 et al $^{11}$ \\
\hline & & Personal travel highways/roads & 25 & Federal Highway Statistics ${ }^{14}$ \\
\hline & & $\begin{array}{l}\text { Sum of the direct household } \\
\text { occupation }\end{array}$ & 172 & \\
\hline Unused lanc & & & 311 & Major Uses of Land in 2012 report $^{2}$ \\
\hline Total land il & & & 2260 & Major Uses of Land in 2012 report $^{2}$ \\
\hline
\end{tabular}

Note:

$48 *$ Includes 254 million acres recreation and wildlife areas 
2. IO-based indirect land use footprint accounting: Converting from producer prices to consumer prices

52 Since the life-cycle land use factors derived from the constructed EEIO are in the unit of per 53 dollar of commodity output, and not per dollar of consumer expenditure, only the fraction of

54 consumer dollars that is received by manufacturing industries should be input into EEIO to

55 determine the associated land use. Personal Consumer Expenditures (PCE) product categories and 56 the IO-sectors producing them have a "many to many" relationship. Similar to previous study ${ }^{15}$,

57 we use 2012 Bridge Tables to Personal Consumption Expenditures ${ }^{16}$ to determine the fraction of 58 consumer dollars received by producers, transportation to market, wholesale trade, and retail trade

59 for each product combination of PCE product category and IO sector. The procedure for 60 calculating a life-cycle land use factor for each product category is as follows:

$$
F_{C, i}=\frac{P V_{i}}{C V_{i}} * F_{P, i}+\frac{T R}{C V_{i}} * F_{P, t r}+\frac{W T}{C V_{i}} * F_{P, w t}+\frac{R T}{C V_{i}} * F_{P, r t}
$$

62 where land use factor (F) is given in consumer dollars (C) or producer dollars (P) for each 63 commodity sector (i). PV represents the total value received by the producing industry (i) of dollars 64 spent by consumers (CV) of commodities from industry (i). Transportation (TR) represents the 65 value received by each sector to ship products to market, while wholesale trade (WT) and retail 66 trade (RT) is the value added from wholesale and retail trade.

67 Life-cycle land use factors based on producer values (Fp) for each commodity sector (i), 68 transportation $(\mathrm{t})$, wholesale trade $(\mathrm{wt})$ and retail trade $(\mathrm{rt})$ can be derived from Equation 2.

69

$$
F_{p}=r(I-A)^{-1}=r L
$$


70 where $r$ is a row vector representing each production sector's land use intensity (i.e., measured by

71 land use per unit total output), $\mathrm{I}$ is the identity matrix, $\mathrm{A}$ is the direct requirements matrix, $\mathrm{L}=(\mathrm{I}-$

$72 \quad$ A $^{-1}$ is the Leontief Inverse Matrix ${ }^{17}$.

73 Each I-O sector produces different PCE products or services. The indirect land use footprint

74 attributed to each of the 214 PCE category can be summed up based on the distribution of

75 consumer spending across different IO sectors, which is also available in BEA's PCE bridge table.

76 In this present study, for the purposes of product-level land use footprint, PCE categories is

77 preferred over other possibly classifications, such as the Consumer Expenditure Survey (CES)

78 classifications provided by the Bureau of Labor Statistics ${ }^{18}$. PCE categories are produced directly

79 from I-O tables and therefore correspond essentially perfectly to the sector-level data provided by

80 IO-LCA models. In addition, comparison studies show that CES only accounts for $60 \%$ of

81 aggregate spending in the PCE. Much of the difference involves categorization issues and potential

82 underestimation, suggesting that consumption studies using I-O approaches should consider using

83 the PCE rather than the $\mathrm{CES}^{19,20 .}$ 


\section{3. Estimation of annual average PCE for US urban and rural residents}

85 Table S2 Estimation of annual average PCE for US urban and rural residents in 2012 (Taking

food expenditure as an illustration, unit: dollar)

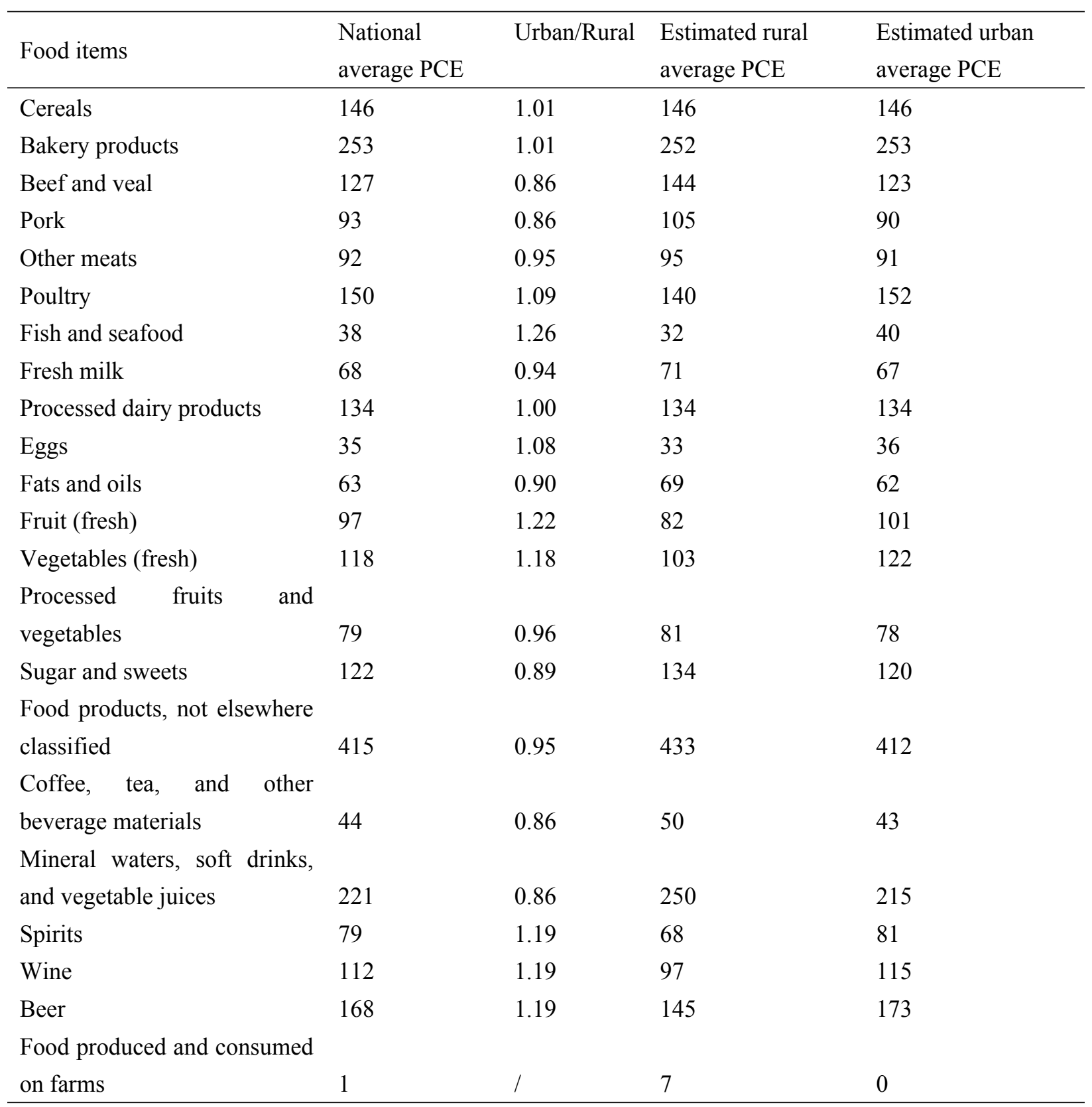




\begin{tabular}{|c|c|}
\hline PCE category & Goods or services \\
\hline Food and beverages at home & Food and beverages at home \\
\hline $\begin{array}{l}\text { Transportation (including vehicles } \\
\text { and fuel) }\end{array}$ & $\begin{array}{l}\text { Motor vehicles and parts, Road transport; rail transport; water transport; } \\
\text { air transport, Auto leasing }\end{array}$ \\
\hline Food services and accommodations & Hotels and restaurants \\
\hline Health care service & Hospital, nursing home and outpatient service \\
\hline Pets, flowers and tobacco & Pets, flowers and tobacco \\
\hline Clothing & Garments; shoes \\
\hline $\begin{array}{l}\text { Furniture and household paper } \\
\text { products }\end{array}$ & Furniture and household paper products \\
\hline Entertainment and recreation & $\begin{array}{l}\text { Recreation goods, vehicles, and services (clubs, museums, gambling, } \\
\text { etc.) }\end{array}$ \\
\hline $\begin{array}{l}\text { Education, social organization and } \\
\text { charity }\end{array}$ & education, child care, social assistance, religious org., charities \\
\hline Medical and personal care products & Drugs, personal care products \\
\hline Real estate service & Rental and leasing, selling houses \\
\hline Utilities & Electricity, water supply, gas, sewage, waste \\
\hline
\end{tabular}




\section{5. The production sector categories and associated production activities}

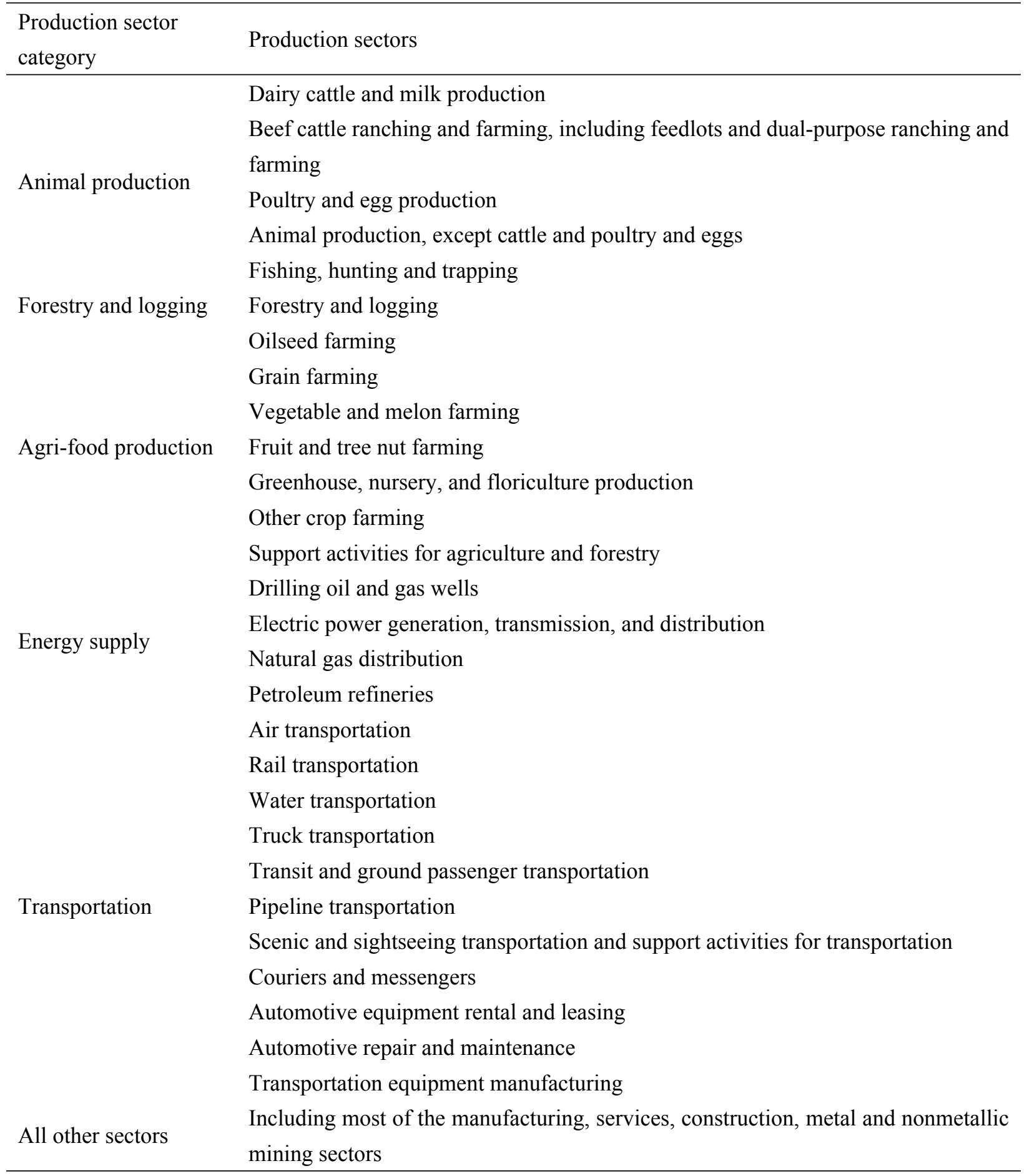




\section{Data processing for scenario analysis}

96 Food waste management, Reducing automobile ownership and driving, Clothing consumption

\section{7 and Paper product consumption change}

98 Based on the environmental input-output model theory explained in the methodology section, the

99 consumption-based supply-chain land footprint quantified in our analysis has a linear relationship

100 with the corresponding personal expenditure categories. Table S5 below shows how we convert

101 the policy interventions to corresponding personal expenditure reductions, and then eventually

102 induce the land footprint reductions.

103 Table S5 Embodied land use in US national average personal consumption categories

\begin{tabular}{|c|c|c|c|c|c|c|}
\hline \multicolumn{2}{|c|}{ Personal Consumption Category } & NIPA line ${ }^{(a)}$ & $\begin{array}{l}\text { Embodied } \\
\text { land footprint } \\
\left(\mathrm{ft}^{2}\right)^{(\mathrm{b})}\end{array}$ & Scenarios & $\begin{array}{l}\text { Induced } \\
\text { expenditure } \\
\text { reduction (\%) }\end{array}$ & $\begin{array}{l}\text { Land } \\
\text { footprint } \\
\text { reduction }\left(\mathrm{ft}^{2}\right)\end{array}$ \\
\hline \multicolumn{2}{|c|}{ Food (exclude beverages) } & $75-93,101$ & 659,037 & $\begin{array}{l}\text { Halving } \\
\text { avoidable } \\
\text { food waste }\end{array}$ & $11.7 \%$ (c) & 10,533 \\
\hline \multirow{2}{*}{ Transportation } & $\begin{array}{l}\text { Car ownership } \\
\text { related }^{(\mathrm{d})}\end{array}$ & $\begin{array}{l}7-20, \\
188,194\end{array}$ & 10,642 & $\begin{array}{l}\text { Reducing } \\
20 \% \text { of car } \\
\text { ownership }\end{array}$ & $20.0 \%$ & 2,128 \\
\hline & VMT related $^{(\mathrm{e})}$ & $111-117$ & 5,007 & $\begin{array}{l}\text { Driving one } \\
\text { day less } \\
\text { weekly }\end{array}$ & $14.3 \%$ & 715 \\
\hline Clothing & & $\begin{array}{l}\text { 102-110, } \\
309\end{array}$ & 7,649 & $\begin{array}{l}\text { Purchase } 10 \\
\text { garments } \\
\text { annually }\end{array}$ & $83.3 \%$ & 6,374 \\
\hline Paper product & & 131 & 3,040 & $\begin{array}{l}\text { Consume as } \\
\text { much as } \\
\text { Italians }\end{array}$ & $50.4 \%$ & 1,531 \\
\hline
\end{tabular}

104 Note:

105 (a). From NIPA (National Income and Product Accounts) Table 2.4.5U. Personal Consumption Expenditures by 106 Type of Product ${ }^{21}$

107 (b). Calculated by USEEIO, see detailed methods in Section 2.1 in main text

108 (c). According to Heller and Keoleian 22 , the food weight availability at the consumer level is $77 \%$ of the primary 109 availability, in which $18 \%$ is estimated as avoidable food waste. Therefore, the induced expenditure reduction 110 by halving avoidable food waste at consumer level is estimated as $9 \% / 77 \%=11.7 \%$.

111 (d). Include consumptions of motor vehicles and parts, motor vehicle maintenance and repair and parking fees 112 and tolls

113 (e). Include consumption of gasoline and other energy goods

114

115 


\section{Diet change:}

117 There are only slightly differences between the food consumed by mass of high- and low-income

118 households in the US ${ }^{15,23}$. Therefore, we estimate the land use intensity embodied per calorie for

119 different food categories by linking an American's average calorific intake and the food 120 consumption categories reported by PCE similar to previous studies ${ }^{15,23}$. The US national average

121 daily per capita calories is taken from USDA Loss-Adjusted Food Availability dataset ${ }^{24}$ (Table $^{\text {The }}$

122 S6). The diet shift from meat to grains one day a week (Meatless Monday program) is then

123 quantified on an iso-caloric basis ${ }^{25}$ (Table SX). That is to say, keeping all other factors constant,

124 one day in a week, we assume the 416 calories intake from meat consumption (NIPA category 78

$125-82$ ) will be transferred to consumptions of cereals and bakery products (NIPA category 75 and $12676)$.

127 Table S6 Average daily per capita calories adjusted for spoilage and other waste (year 2010)

\begin{tabular}{cccccccccc}
\hline Meat & Eggs & Nuts & Dairy & Fruit & Vegetables & $\begin{array}{c}\text { Flour and } \\
\text { cereal } \\
\text { products }\end{array}$ & $\begin{array}{c}\text { Added fats } \\
\text { and oils and } \\
\text { dairy fats }\end{array}$ & $\begin{array}{c}\text { Sugar and } \\
\text { sweeteners } \\
\text { (Added) }\end{array}$ & $\begin{array}{c}\text { Total } \\
\text { (Added }\end{array}$ \\
\hline 416 & 38 & 72 & 235 & 86 & 130 & 581 & 575 & 373 & 2,507 \\
\hline
\end{tabular}

129 Relocation choices:

130 Moving from Minneapolis-St Paul (MSP) Metropolitan Statistical area (MSA) to New York

$131 \quad \boldsymbol{M S A}$

132 We've added the residential lot area plus the road area change as the total direct land use change

133 for this relocation scenario. Data for the average single-family housing lot sizes across different

134 US MSAs are taken from American housing survey ${ }^{10}$. The miles of roadway per 1000 persons

135 across different US urbanized areas are taken from Table HM-72 of Highway Statistics 2017 by 
136 US Federal Highway Administration ${ }^{26}$. We assume an average width of 12 feet for the road lanes

137 to quantify the road area reduction while relocating.

138 Moving towards urban center within a transit shed in MSP MSA

139 We only consider the residential lot area change as the total direct land use change for this

140 relocation scenario since the 4 selected cities (i.e., St Paul, Roseville, Arden Hills, and North Oaks)

141 locate in the same transit shed. Statistics for single- and multi-family housing lot sizes and floor 142 areas of these 4 cities are derived from Ramsey county's tax-parcel level land use data. A typical

143 parcel-level land use data, in the form of either.csv or GIS shapefile, records the building type, lot 144 size area, floor area, etc. for a specific residential property.

145 Relocation from a single-family residence to a multi-family within the same cities in MSP MSA

146 For this scenario, we take the average of the lot size differences between single- and multi-family

147 housing across 3 cities: St Paul-urban center, Roseville-urban, Arden Hills-suburban as the total 148 direct land use change.

149 For the first two relocation scenarios, we also consider the indirect CBLF reduction caused by 150 reduced car ownership and VMT while moving. Automobile ownership for different MSAs and 151 cities are from the estimates of 2018 Esri Market Potential Database, in which the average 152 household automobile ownership is available at the US census block group level ${ }^{27}$. The VMT data 153 is taken from the LATCH Survey from Bureau of Transportation Statistics ${ }^{28}$, which reports the 154 average household VMT at US census tract level ${ }^{28}$. 


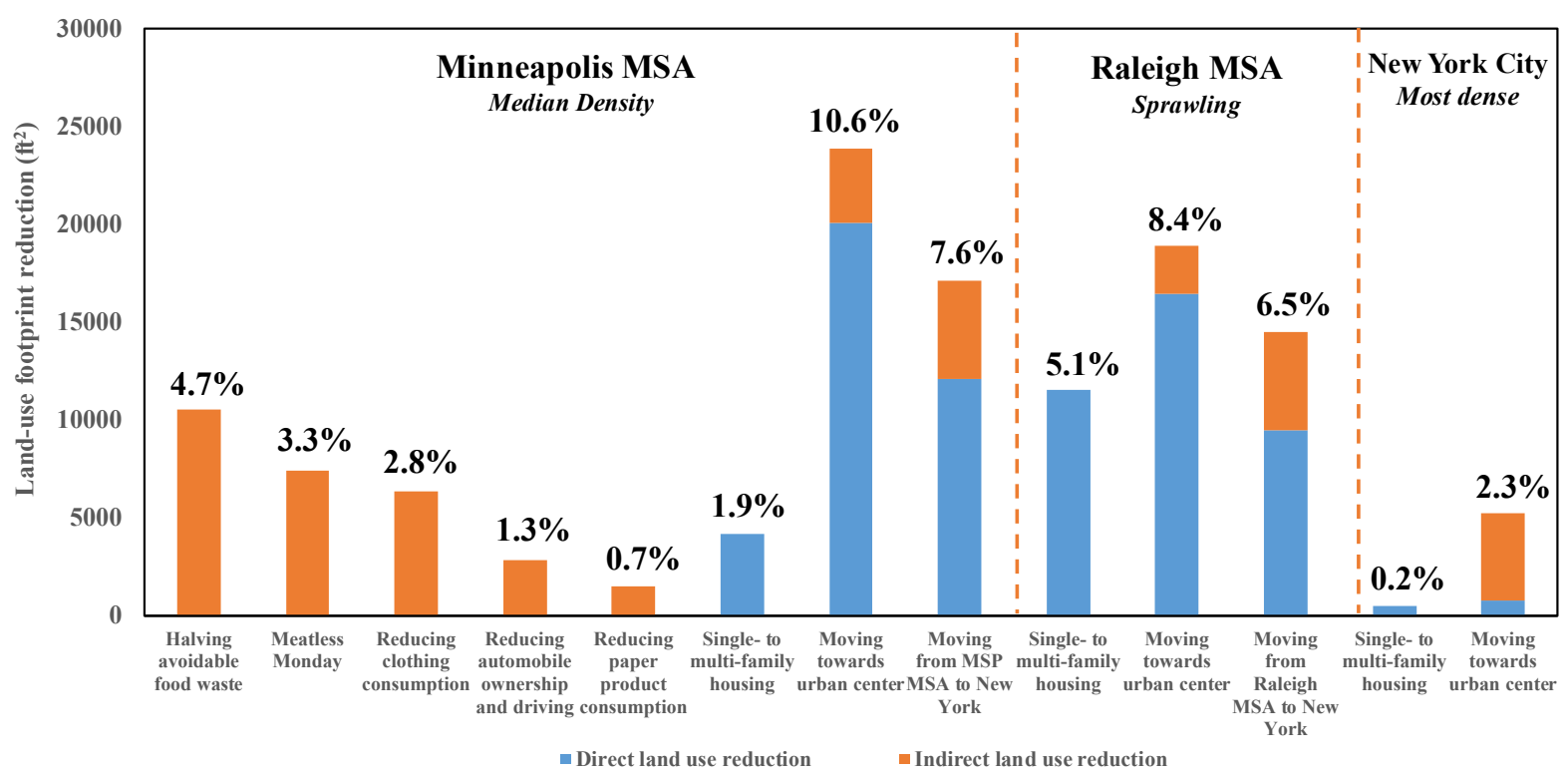

Figure S1 Land footprint reduction potentials by relocation choices in different US metro areas 


\section{8. Uncertainty analysis of land use footprints}

\section{$158 \quad$ 8.1 Land Use Data Comparisons}

159 Land use values in this study were compared to land use areas in two widely used MRIO

160 database: WIOD $^{29}$ and Eora ${ }^{30}$. A summary is provided below in Table S5. Due to data availability,

161 we focus on the area comparisons for cropland, pastureland and productive forest land (i.e., forest

162 used for economic activities). The values used in this study compare reasonably well with the other

163 two datasets. Differences can be attributed to different definitions for land use categories and

164 different study years. The differences in the areas assigned to each land type also provide insight

165 to the potential range of land use footprint uncertainty, which is further discussed in 6.2 .

166 This study primarily uses land data from the year 2012. The most recent Eora data are from 2012

167 and the WIOD data are from 2009, making this comparison feasible. Note that in this study we use

168 the USDA MULR definition of pastureland, which includes a subcategory for grazed forestland.

169 Meanwhile, the values for grazed land in WIOD and Eora follow the United Nations Food and

170 Agricultural Organization definition of pastureland, which mainly includes "permanent meadows

171 and pastures". The amount of grazed forestland estimated by the USDA MULR is 52.6 Mha in

1722012 in U.S. If it can be assumed that this value is not included in the WIOD and Eora pastureland

173 estimate, this would close the gap between estimates considerably.

174 WIOD estimated the productive forest land area on the basis of the Global Forest Resource

175 Assessment 2005 published by $\mathrm{FAO}^{31}$. Eora does not distinguish if the forest is used for economic

176 activities or for other non-economic purposes in the satellite accounts. Therefore, we did not

177 include it in the land area comparison. 
Table S7. Comparison of land use data in this study and two MRIO databases (Unit: 1000 ha)

\begin{tabular}{lllllll}
\hline & Cropland & $\begin{array}{l}\text { Animal land } \\
\text { (Pasture/Grazed } \\
\text { land) }\end{array}$ & $\begin{array}{l}\text { Adjusted }^{*} \\
\text { animal land }\end{array}$ & $\begin{array}{l}\text { Productive } \\
\text { forest land }\end{array}$ & $\begin{array}{l}\text { Developed } \\
\text { Land }\end{array}$ & Mining \\
\hline This study & 153,379 & 322,946 & 322,946 & 203,104 & 12,545 & 16,592 \\
WIOD & 165,451 & 238,000 & 290,610 & 176,326 & NA $^{* *}$ & NA \\
Eora & 157,707 & 250,999 & 303,609 & NA & NA & NA \\
\hline SD $^{* * *}$ & $4.0 \%$ & -- & $5.0 \%$ & $9.3 \%$ & -- & -- \\
\hline
\end{tabular}

Note:

$180 *$ Add 52.6 Mha grazed forest land (estimated by USDA) to pastureland area in WIOD and Eora

*** SD: relative standard deviation, divide the calculated SD by land area values used in this study

\subsection{Uncertainty analysis using the standard error propagation method} comparisons in Section 7.1, we further take a 5\% of uncertainty for the economic statistics in IO table. According to the error propagation method based on Taylor series expansion (Equation S1), and the basic function in $\mathrm{IO}$ accounting (Indirect $\mathrm{CBLUF}=\mathrm{B}^{*} \mathrm{~L} * \mathrm{PCE}$ ), the standard deviation of indirect consumption-based land use footprint $\left(\sigma_{f}\right)$ can be calculated with 
197 We should also note that the world average land use intensities are actually higher than the US 198 average (both from literature ${ }^{33}$ and calculated from the MRIO databases), which indicates that the 199 indirect portion of an average American consumer's consumption-based land use footprint will 200 increase if global imports are considered. Thus, our results provide a conservative lower-end 201 estimate of the CBLUF quantification.

202

203 
205 1. USDA. 2012 Census of Agriculture.Table 8. Land: 2012 and 2007; United States Department of 206 Agriculture: Washington DC, 2014.

207 2. Bigelow, D. P.; Borchers., A. U.S. Department of Agriculture, Economic Research Service, Major Uses of 208 Land in the United States, 2012. 2017.

209 3. USDA. Land Use and Land Cover Estimates for the United States. https://www.ers.usda.gov/about$210 \mathrm{ers} /$ partnerships/strengthening-statistics-through-the-icars/land-use-and-land-cover-estimates-for-the-united-

211 states/\#e, (accessed November 30, 2018),

212 4. Yang, Y.; Ingwersen, W. W.; Hawkins, T. R.; Srocka, M.; Meyer, D. E. USEEIO: A new and transparent 213 United States environmentally-extended input-output model. J. Clean. Prod. 2017, 158, 308-318.

214 5. USDA. 2012 Census of Agriculture.Table 51. Selected Characteristics of Farms by North American 215 Industry Classification System: 2012; United States Department of Agriculture: Washington DC, 2014.

216 6. BLM. 2012 Public Land Statistics; BLM/OC/ST-13/002+1165; U.S. Department of Interior, Bureau of 217 Land Management: Washington DC, 2013.

218 7. U.S. Bureau of Economic Analysis. 2012 Input-Output Accounts Data. 219 https://www.bea.gov/industry/input-output-accounts-data (accessed November 30, 2018),

220 8. EIA 2012 Commercial Buildings Energy Consumption Survey (CBECS). 221 https://www.eia.gov/consumption/commercial/reports/2012/energyusage/index.php

222 9. EIA 2010 Manufacturing Energy Consumption

223 https://www.eia.gov/consumption/manufacturing/data/2010/ (accessed November 30, 2018),

224 10. U.S. Department of Housing and Urban Development. American Housing Survey Datasets 2013-2015.

225 https://www.census.gov/programs-surveys/ahs.html (accessed April 1, 2018),

226 11. Larson, L. R.; Jennings, V.; Cloutier, S. A. Public parks and wellbeing in urban areas of the United States.

227 PLoS One 2016, 11 (4), e0153211.

228 12. U.S. Federal Highway Administration. Highway Statistics 2012. Table HM-60. Functional system lane229 length 2012. https://www.fhwa.dot.gov/policyinformation/statistics/2012/hm72.cfm (accessed February 1, 230 2019),

231 13. Scharnhorst, E. Quantified Parking: Comprehensive parking inventories for five U.S. Cities; Research 232 institute for housing America: 2018.

233 14. U.S. Department of Transportation. Addendum to the 1997 Federal Highway Cost Allocation Study Final 234 Report. Table 6. Federal User Fee Payments by Vehicle Class. 235 https://www.fhwa.dot.gov/policy/hcas/addendum.cfm (accessed April 1, 2018),

236 15. Jones, C. M.; Kammen, D. M. Quantifying carbon footprint reduction opportunities for U.S. households 237 and communities. Environ. Sci. Technol. 2011, 45 (9), 4088-4095.

238 16. U.S. Bureau of Economic Analysis. 2012 Personal Consumption Expenditure Bridge Table. 239 https://www.bea.gov/industry/industry-underlying-estimates (accessed November 30, 2018),

240 17. Miller, E. R.; Blair, D. P., Input-Output Analysis: Foundations and Extensions (Second Edition). 241 Cambridge University Press: Cambridge, UK, 2009.

242 18. U.S. Bureau of Labor Statistics. Consumer Expenditures Survey $2012 . \quad$. 243 https://www.bls.gov/cex/csxcombined.htm (accessed December 10, 2018),

244 19. U.S. Bureau of Labor Statistics. Comparing expenditures from the Consumer Expenditure Survey with the 245 Personal Consumer Expenditures: Results of the CE/PCE Concordance.

246 https://www.bls.gov/cex/cepceconcordance.htm (accessed September 30, 2018), 
20. Garner, T. I.; Janini, G.; Passero, W.; Paszkiewicz, L.; Vendemia, M. The CE and the PCE: a comparison. Mon. Lab. Rev. 2006, 20-46.

249 21. U.S. Bureau of Economic Analysis. Table 2.4.5. 2012 Personal Consumption Expenditures by Type of 250 Product. https://apps.bea.gov/iTable/iTable.cfm?reqid=19\&step=2\# (accessed November 30, 2018),

251 22. Heller, M. C.; Keoleian, G. A. Greenhouse gas emission estimates of U.S. dietary choices and food loss. $J$. 252 Ind. Ecol 2015, 19 (3), 391-401.

253 23. Goldstein, B. P.; Hauschild, M. Z.; Fernández, J. E.; Birkved, M. Contributions of Local Farming to Urban

254 Sustainability in the Northeast United States. Environ. Sci. Technol. 2017, 51 (13), 7340-7349.

255 24. USDA ERS. Food Availability (Per Capita) Data System. https://www.ers.usda.gov/data-products/food256 availability-per-capita-data-system/ (accessed February 1, 2019),

257 25. Boyer, D.; Ramaswami, A. What is the contribution of city-scale actions to the overall food system's 258 environmental impacts?: Assessing water, greenhouse gas, and land impacts of future urban food scenarios. 259 Environ. Sci. Technol. 2017, 51 (20), 12035-12045.

260 26. U.S. Federal Highway Administration. Highway Statistics 2012. Table HM-72. Urbanized area summaries. 261 https://www.fhwa.dot.gov/policyinformation/statistics/2012/hm72.cfm (accessed February 1, 2019),

262 27. Esri 2018 Market Potential Database. https://doc.arcgis.com/en/esri-demographics/data/market263 potential.htm (accessed April 1, 2019),

264 28. U.S. Bureau of Transportation Statistics. Local Area Transportation Characteristics for Households 265 (LATCH Survey). https://www.bts.gov/statistical-products/surveys/local-area-transportation-characteristics266 households-latch-survey (accessed April 1, 2019),

267 29. Timmer, M. P.; Dietzenbacher, E.; Los, B.; Stehrer, R.; de Vries, G. J. An illustrated user guide to the world 268 input-output database: the case of global automotive production. Rev. Int. Econ. 2015, 23 (3), 575-605.

269 30. Lenzen, M.; Moran, D.; Kanemoto, K.; Geschke, A. Building Eora: a global multi-region input-output 270 database at high country and sector resolution. Econ. Systems Res. 2013, 25 (1), 20-49.

271 31. Food and Agriculture Organization of the United Nations. Global Forest Resources Assessment 2005; FAO 272 Forestry Paper 147; Rome, 2006.

273 32. Oita, A.; Malik, A.; Kanemoto, K.; Geschke, A.; Nishijima, S.; Lenzen, M. Substantial nitrogen pollution 274 embedded in international trade. Nature Geoscience 2016, 9, 111.

275 33. van Vliet, J. Direct and indirect loss of natural area from urban expansion. Nature Sustainability 2019, 2 276 (8), 755-763. 